\title{
Explore the Development of the New Collective Economics of Rural Guizhou
}

\author{
Zhuping Zhang ${ }^{1} \quad$ Juan Du \\ ${ }^{1}$ GuiZhou University of Finance and Economics, Guiyang 550004, China \\ ${ }^{2}$ Party School of the CPC Guiyang Committee Wudang District Sub-committee, Guiyang \\ 550004, China
}

\begin{abstract}
Because of the inborn feebleness of agriculture, agriculture will face the risk of natural disaster and market risk which is caused by the relationship between supply and demand. The small-scale peasant economic development model of the household can't meet the demand of the development of the socialist market economy which brings the economical development model of appropriate scale into being. According to peasant professional cooperation which is led by rural "Branch and rural committee" and the country's new collective economical organization, which is led by peasant households, the two also adapt to the demand of the appropriately scaled economical development model. It not only makes the rural collective economy obtain capital accumulation, but it also causes the peasant to be rich, which is caused by increasing income.
\end{abstract}

\section{Keywords}

Rural Guizhou; Collective economics

\section{发展贵州农村新型集体经济的探索}

\author{
张筑平 ${ }^{1}$ 杜鹃 $^{2}$ \\ 1 贵州财经大学，贵阳 550004，中国 \\ 2 中共贵阳市乌当区委党校, 贵阳 550004, 中国
}

摘要：由于农业的天生弱质性，农业生产将面临着自然灾害风险和由供求产生的市场风险， 一家一户的小农经济发展模式将很难适应社会主义市场经济发展需要，适度规模经济发展模 式应运而生, 以村 “两委” 领办农民专业合作社加农户的农村新型村集体经济组织, 正好适 
应了适度规模经济发展模式需求, 不仅使村集体经济得到资本累积, 而且使农户增收致富。 关键词: 贵州农村; 新型村集体经济

\section{0.引言}

自新中国成立以来，党和政府一直 高度重视农村发展，在将近 70 年的时 间里实施了三次大的土地变革, 从打土 豪分田地到高度集体化的人民公社，又 从人民公社到家庭联产承包责任制, 三 次变革都是历史的必然, 都在一个历史 阶段起到了积极作用, 都为解放和发展 农村生产力做出过贡献。如今, 实行了 30 多年的家庭联产承包责任制, 在社会 主义市场经济进一步推进过程中, 暴露 出了诸多的缺点和弊端。主要体现在:

（1）农户不能自由处置土地, 限制了 农户的择业自由。（2）家庭小块土地 分散经营, 增加了农业生产的管理成 本; (3) 家庭分散经营, 经营规模过 小，难以形成规模经济效益; (4) 农 村基础设施难以建设, 农业生产长期高 成本, 农户靠天吃饭的局面难以改变。

纵观改革开放以来一般农村经济较 发达的地区, 农村集体经济也是比较发 达的, 发展后劲也比较足。而一些集体 经济逐渐衰退的村庄, 农户经济越来越 受到限制, 特别是在面对市场经济时, 一家一户的农户经营机制越来越缺乏 竞争力, 这就需要由集体经济来组织与 协调。贵州省作为全国农村经济欠发达 省份, 在家庭联产承包责任制推行 30 多年来, 农村经济, 特别是农户经济有 了长足的进步, 但与全国平均水平相比 又是远远落后的, 这无不与我省农村集 体经济的发展关系极大。因此, 对我省
发展农村新型集体经济进行探讨, 具有 重要的理论价值和现实意义。

首先对贵州农村固定观察点 10 个 村的村集体经济情况进行实证分析, 之 后结合大量的实证调研，从而探索贵州 农村新型集体经济发展的路子。

\section{1.贵州 10 村村集体经济变化情况}

\section{1 贵州 10 村村集体固定资产拥有情 况}

从贵州省全国农村固定观察点 10 个村村集体固定资产拥有水平来看, $\mathrm{n}$ 农户人均拥有村集体固定资产原值的 水平是逐年提高的, 由 2011 年的人均 98.2 元, 增加到 2015 年的人均 122.5 元。 而从构成来看，村集体拥有的固定资产 主要是房屋和场地, 占到了 $85 \%$ 左右, 还有就是为改善农户生产条件, 而由政 府兴建的水利设施, 为改善农户生活水 平而兴建的饮水设施以及为改善农村 生活环境而兴建的垃圾污水处理设施。 至于为增强农业生产发展后劲的农林 牧渔业机械、工业建筑业机械、运输机 械、动力和电力设备等全部没有。

再从 2015 年贵州 10 村各村集体固 体资产拥有水平及构成来看, 有 6 个村 的村集体固定资产全部是房屋和场地, 他们分别是水洞村、八总村、褚家山村、 灯塔村、长春村和包包寨村。有 3 个村 
有水利设施，分别是小场坝村、江西村 和麦穰村。 2 个村有饮水设施, 分别是 麦穣村和镇江村。1 个村有垃圾污水处 理设施, 是平坝的江西村。除了村集体 固定资产拥有房屋和场地外，同时拥有 两项村集体固定资产的村是，平坝的江 西村拥有水利设施和垃圾污水处理设 施，乌当的麦穰村拥有水利设施和饮水 设施。

通过以上分析，可以看出，贵州 10 村村集体固定资产的人均拥有水平不 仅低，而且构成相对都比较单一，这些 对促进农村农户的农业生产和经济发 展都是十分不利的。

\section{2 贵州 10 村村集体经营收入水平及 构成}

从贵州 10 村村集体经营收入及构 成来看，没有什么规律可寻，在 2011 年、2013 年和 2015 年 3 个时间节点上, 2013 年收入水平最高, 达到人均 128.1 元, 其构成主要是征地款收入占 $83.86 \%$, 还有就是上级补助款占 $11.64 \%$ 。而 2011 年收入水平为人均 56.8 元, 其构成主要是上级补贴款占 $52.57 \%$ 和征地款收入占 $38.24 \%$ 。再来看 2015 年, 村集体经营收入人均只有 26.0 元, 主要就是上级补助款占 $84.95 \%$ 。

再从 2015 年各村村集体经营收入 水平及构成看, 有 4 个村的村集体经营 收入全部是上级补助款, 分别是水洞 村、八总村、麦稿村和镇江村, 相对应 也有 3 个村没有上级补助款收入，分别 是褚家村、灯塔村和包包寨。也就是说, 如果缺了上级补助款这一项收入来源,
7 个村将没有任何村集体经营收入来 源, 占到了被调查村的 $70 \%$ 。再看其他 3 个村, 平坝的江西村, 村集体经营收 入人均 4.3 元, 主要是征地款收入占 90.09\%; 安龙的小场坝村, 村集体经营 收入人均 14.0 元, 主要是其他经营收入 占 $68.38 \%$ 和出租房子和场地收入占 $27.92 \%$; 遵义的长青村, 村集体经营收 入人均 15.4 元, 主要是其他经营收入占 $49.63 \%$ 和上级补助款收入占 $38.32 \%$ 。从 以上分析可以看出贵州 10 村基本上是 没有可持续的村集体经济收入来源的。

\section{3.贵州 10 村村集体财务收支情况}

从村集体财务收入看，对上级部门 具有高度依赖性。在上级部门拨款中村 组干部工资又是大头, 其次是维持村两 委的办公正常运转。至于村集体经营性 收入、出租村集体资产收入和企业上缴 款收入，所占村集体财务年内收入来源 的比重都不大, 高的时候能占到百分之 十几，低的时候只有百分之几，倒是其 他收入在 2011 年和 2013 年分别占到了 $41.06 \%$ 和 $46.58 \%$ 。总的来看， 10 村村 集体财务收入的水平较低, 而且渠道也 比较单一。

再从村集体财务的支出来看, 突 高、突低, 大多数年份都是低水平连转, 有 2 年支出大于收入, 分别是 2012 年 和 2013 年, 2012 年主要是用于为农户 提供服务占到了 $72.11 \% ， 2013$ 年则主 要是用于为农户提供服务占 $30.36 \%$ 和 公益事业占 $40.21 \%$ 。在村集体财务支出 的构成中，行政管理费的支出是主要的 支出项，在行政管理费的支出中，支付 
给村组干部的工资和补贴又占了大头, 而随着中央八项规定的具体落实，招待 费用的支出大幅度减少。总的来看, 村 集体财务支出主要还是行政管理费用, 占了支出的大头，而为农户提供服务和 公益事业的支出占比都不高。

\section{4 结论性评述}

通过对全国农村固定观察点贵州 10 个村的调查统计分析, 可以看出, 贵 州农村村集体经济不仅弱小，而且还长 期处于徘徊的状态, 停留在有和无的层 面上, 还谈不上发展和壮大的问题。贵 州 10 个村除了村集体的房屋和场地, 以及少量的水利设施、饮水设施外, 就 没有其他的村集体固定资产了, 水利设 施也只是 3 个村有, 饮水设施也只是 2 个村有。再从 10 个村村集体经营收入 看, 有 4 个村全部是上级补助款, 有 3 个村村集体经营收入为 “ 0 ”, 有村集 体经营收入的 3 个村, 其村集体经营收 入也是少得可怜。最后从村集体财务的 收支情况来看, 其收入和支出也主要是 用于村 “两委” 干部的工资和补贴, 用 于为农户提供服务的支出, 用于村公益 事业的支出则是占很小的比例。实际上 村党政干部不是不想为广大的农民办 好事、办实事, 只是苦于无钱可支。贵 州 10 村的现状, 正如习近平总书记, 2017 年 6 月 23 日 “在深度贫困地区脱 贫攻坚座谈会上的讲话” 中提到的, “全 国 12.8 万个建档立卡贫困村居住着 $60 \%$ 的贫困人口, 基础设施和公共服务 严重滞后, 村委班子能力普遍不强, 四 分之三的村无合作经济组织, 三分之二
的村无集体经济, 无人管事、无人干事、 无钱办事现象突出。”

\section{2. 发展贵州农村新型集体经济的探索}

\section{1 农业小农经济发展模式}

自从我们国家改革开放以来, 在广 大农村实行了 30 多年的家庭联产承包 责任制, 极大地调动了广大农民农业生 产的积极性, 极大地释放了农村的农业 生产力, 使农村经济, 特别是农户经济 有了长足的发展。由于农业生产的天生 弱质性, 即农业生产不仅受着自然灾害 的影响, 还受着市场经济中供求矛盾的 影响。使得分散承包的小农生产难以形 成高度组织化的社会大生产, 这种小农 经济发展模式是一种在土地规模约束 下的, 以生存导向为基础追求的以农户 家庭为基本单位的农业发展范式。伴随 着工业化、城镇化的进一步深入推进, 在社会主义市场经济改革浪潮下的中 国社会正经历着从 “乡土中国” 到 “城 乡中国” 的转变, 以农业人口外流为基 本特征的新型人地关系既塑造着城市, 也影响着农村, 我国小农经济式的农业 发展模式也经历着新的变化。在农村人 口外流背景下, 土地流转已成大势所 趋, 土地的规模化经营日渐提上了党和 政府的议事日程, 随之而来的三权 (土 地所有权、承包权、经营权) 分离更是 从政府的政策上提高保障, 农业经营主 体已实现从单一的承包农户向多元的 新型农业经营主体转变, 农业规模化、 产业化经济发展模式将随之产生。 


\section{2 农业规模经济发展模式与小农经 济发展模式比较}

农业规模经济发展模式就是以新 型农业经营主体为主导的靠适度土地 规模经营取胜为特征的发展模式。小农 经济发展模式所强调的市场结构实际 上类似于一个完全竞争市场，农产品大 多同质而单一，农户在市场上是没有定 价权, 他们只是价格的接受者。而农业 规模经济发展模式下的农业则明显不 同, 较大规模的土地, 专业化的农业生 产, 使得它面临的市场近似于一种介于 垄断竞争市场与完全竞争市场之间的 市场形态，市场议价能力明显提高。

农业规模经济发展模式的优势并 不仅仅体现在市场议价能力上。与小农 经济发展模式的目标设置不同, 农业规 模经济模式所强调的不是生存温饱型 的风险规避式的收入增长, 它的目标定 位在赚取高额收益的基础上, 将农业看 成是有前景、有前途的农业。

\section{3 发展贵州新型农村集体经济的探 索与思考}

通过以上对小农经济发展模式与 农业规模经济发展模式的比较, 可以看 出在当今的中国, 农业规模经济发展模 式是比较适宜的, 那农业规模经济发展 的经营主体又由谁来担当呢?无疑就需 要发展新型农村集体经济组织来承担。

贵州在全国属老少边穷地区, 贫困 程度深, 贫困面积大, 生态环境恶劣。 在全国各地打赢脱贫攻坚战让贫困群 众与全国人民同步迈入小康的背景下，
如何实现贵州农村和贫困户脱贫致富 奔小康, 已成为全省各级党委政府的工 作重点。笔者通过对贵州农村实地调 研, 并结合当地实际, 认为通过村 “两 委” 领办农民专业合作社并让贫困农户 入股合作社是发展贵州农村村级集体 经济较好的方式, 这是脱贫攻坚的现实 需要, 也是解决贵州农村因为缺少人 才、资金、理念而发展滞后的有力探索。

所谓农村集体经济是指村集体组 织通过出租集体资产、入股、外包、流 转等方式取得经营性、服务性收益的一 种公有制经济。发展壮大村集体经济是 加强党的基层组织建设, 提高党的为民 服务能力, 巩固党的执政地位和执政基 础的重要保证, 也是贫困农户脱贫增收 的重要手段。

（一）如何发展壮大贵州农村村集 体经济呢?

一是可以通过村 “两委” 领办农民 专业合作社发展村集体经济。要充分发 挥村级党组织在推进农村基层治理和 农户增收致富中的核心引领作用, 采取 “村” 两委” +村级集体经济组织（农 民专业合作社）+农户+产业” 的方式， 引导贫困农户和非贫困农户按不同的 出资比例筹资入股农民专业合作社, 加 上专项扶贫资金作为村集体经济组织 发展的启动资金, 发展山区特色种养殖 业。

二是要借助各方资源发展特色产 业, 通过各级政府部门的扶贫项目资 金，引领民营企业等多元化社会资本向 农村集体产业项目聚集, 利用村集体的 荒山、荒地及农户的土地, 通过成立农 民专业合作社, 找准路子、精准施策、 
按照利益共享、风险共担的原则, 实行 “统一质量标准、统一品牌包装、统一 生产经营、统一生产技术、统一疫病防 控、统一收储销售”，提升农民专业合 作社的组织功能, 构建和完善产业链条 中的利益联结机制; 通过农民专业合作 社为村民提供农资供应、农产品购销、 科技指导等服务增加村集体经济组织 收入。

（二）规范发展贵州农村农民专业 合作社的建议

农村集体经济的发展，主要以村 “两委”领办农民专业合作社+农户的 方式来运行，为此对规范发展农民专业 合作社的建设提出如下建议。

（1）在农民合作社的架构上，推 动规范发展

一是强化政策支持。突出目标导 向, 推动多元发展, 注重规范建设, 促 进产业融合，精准施策发展壮大农民合 作社。二是加大指导服务力度。对合作 社主要管理人员进行轮训, 培养一批专 业人才。明晰产权关系规范财务管理、 完善运行机制等，促进合作社规范有序 发展。三是强化组织领导。整合各级各 部门资源, 密切协调配合, 形成合力推 动农民合作社发展壮大。

(2) 提升合作社发展能力，做大 做强合作社。

一是推进规模化生产。引导合作社 有序流转土地, 以市场为导向, 集中连 片发展种植业, 推进规模化养殖, 建设 一批种植养殖基地, 打造特色优势产业 群、产业带, 提高农业规模效益。二是 推行标准化生产。鼓励农民合作社统一 种植标准、质量、包装、产地认证等。
三是强化科技创新。鼓励和引导农业在 岗科研人员创办、领办、参办农民合作 社, 着力提高土地产出率和劳动生产 率。

（3）推进精准扶贫，促进农户增 收。

一是广泛吸收农民入社。尤其是贫 困户参加合作社，让农户分享产业发展 增值收益，促进农户增收致富。二是完 善村 “两委” +村集体经济组织（合作 社）+农户运作模式。带动贫困农户发 展生产增加收入。

（4）加强产供销衔接，拓展销售 渠道

一是拓展农产品销售渠道。积极推 进 “农社对接”、“农企对接”、“农 校对接”、“农超对接” 等市场流通新 模式, 降低流通成本, 提高农产品流通 效率。二是做好信息判断分析。利用大 数据技术加强农产品销售信息跟踪, 及 时了解各地生产和销售状况, 引导合作 社生产适销对路产品。

\section{参考文献}

[1] 胡继连.中国农户经济行为研究 [M] 北京: 农业出版社 1992.

[2] 史清华.农户经济可持续发展研究 [M] 北京：农业出版社 2005 .

[3] 贵州省农业委员会.农村社会经济调 查（2011-2015 年）。 